\title{
Hereditary genius revisited: Were Galton's missing scientists the aftermath of the Puritan brain drain to America?
}

\author{
PHILIP HOWARD GRAY \\ Montana State University, Bozeman, Montana 59717
}

\begin{abstract}
This is a sociobiological analysis using history and genealogy to inquire into the hereditary genius of science. It combines Francis Galton's data on the geographical origins of English scientists and Charles Banks' data on similar origins of English immigrants to New England to show a probable brain drain as a result of the Puritan emigration that had an effect lasting even into Victorian times.
\end{abstract}

In his justly famous English Men of Science, Sir Francis Galton was concerned with the nature and nurture of British scientists (Galton, 1874). Among his findings was the discovery that an irregular plot marked on the map of his country could include less than half its area but more than $95 \%$ of the known birthplaces of his subjects. There were large areas, said Galton, that were very deficient in aboriginal science (Figure 1). These areas included East Anglia, coastal Wales, most of the northern counties, Scotland immediately above the Firths of Clyde and Forth, the outer coast of Cornwall, that portion of Devon surrounding Plymouth, and most of the areas south of the Bristol Channel.

Galton (1874) did not attempt to explain the meaning of this distribution, and no one else appears to have tried to explain it. But a few years ago, I found a curious relationship between Galton's study of English scientific genius and the Puritan migration to America. The significance of Galton's discovery can be clarified, provided that two premises are given tolerance.

First, genius, as Galton indicated in his earlier Hereditary Genius, runs in families and may, in a sense, be said to be inherited biologically (Galton, 1869). Now, as then, an implication of biological determinism is summarily rejected by those scientists who do not, as has been pointed out, realize the theoretical value of having this option at hand (Davis, 1975). Fancher's (1982) recent criticism of Galton in Africa is an example of how easy it is to confuse the scientific logic of behavioral provenance with a contemporary moral ideology.

Second, the intellectual class, or, rather, that class that produced English intellectuals, tended to remain long periods in definite locations, for reasons that need not be discussed now. There is, however, a substantial literature speaking to the geographical stability of the English landed class (Breen, 1978; Cole, 1978).

Actually, the data to be presented here are not all that new, but they are generally unknown except to genealogists, and since there are very few genealogists who are knowledgeable enough in science to be interested in Galton, it is not surprising that the juxtaposition had waited nearly half a century for a scientist interested in Galton to acquire a rudimentary knowledge of genealogy, it being almost that long ago that the genealo-

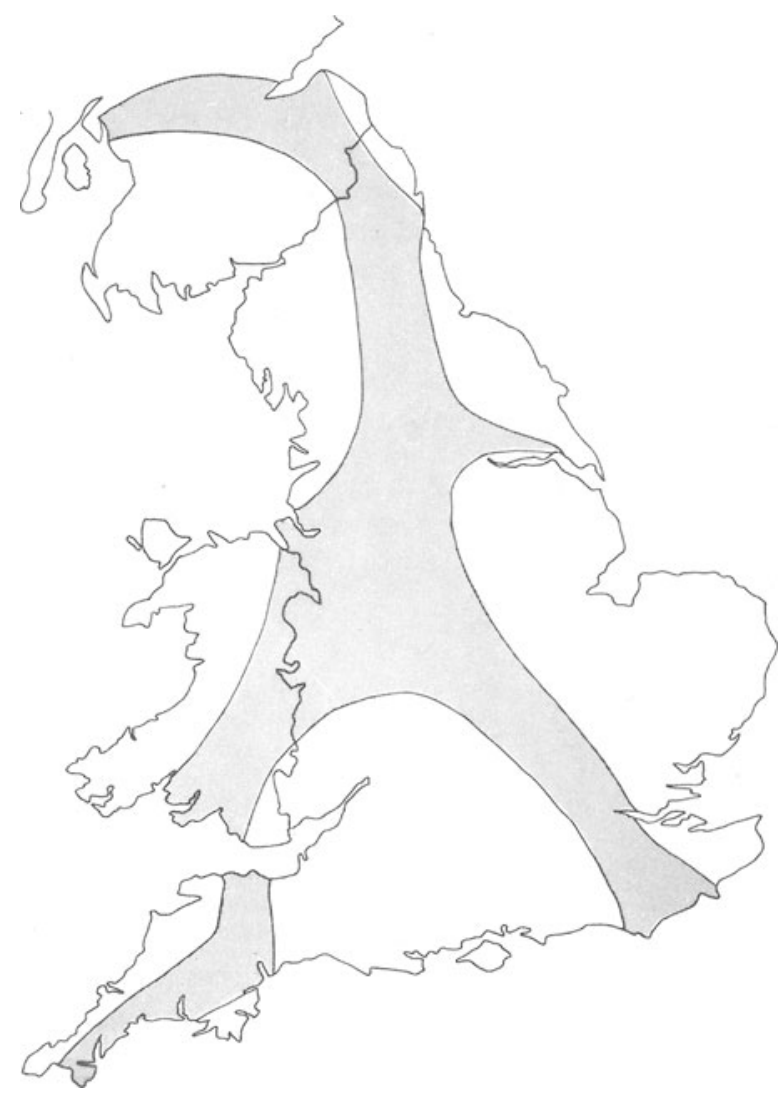

Figure 1. Galton's map of England with the shaded area covering less than half its land but representing the birthplaces of more than $95 \%$ of the English scientists whom Galton, in 1874 , deemed eminent. 
gist and antiquary Charles Edward Banks published his The Planters of the Commonwealth (Banks, 1930). This was a study, using record evidence, of the county origins, ships and masters of transportation, dates of departure and arrival, and eventual destination of over 2,600 heads of English families who came to New England between 1620 and 1640 . According to an earlier study on the pioneers of Massachusetts, about 6,000 families left some record of themselves in the Massachusetts colonies of that time; hence we know the county origins of nearly half of those heads of families who are known to have come in the Great Migration, so called (Pope, 1900).

Figure 2 is a density map based on Banks' (1930) figures. It is a complement of Figure 1 that is redrawn from Galton's (1874) map of the birthplaces of British scientists. The maps would be even more negatively related if additional facts were considered. For example, many Welsh migrated to Pennsylvania before Galton made his study, as did many Scots (Glenn, 1911-1913/1970; Hanna, 1902/1968). Additionally, many of the Lincolnshire emigrants, like those from Yorkshire, were from the coastal areas, whereas most of the Devon and Cornwall emigrants were from the small area around Plymouth (Banks, 1937).

The conclusion is fascinating. The New England migration of $1620-1640$ seems to have drained away

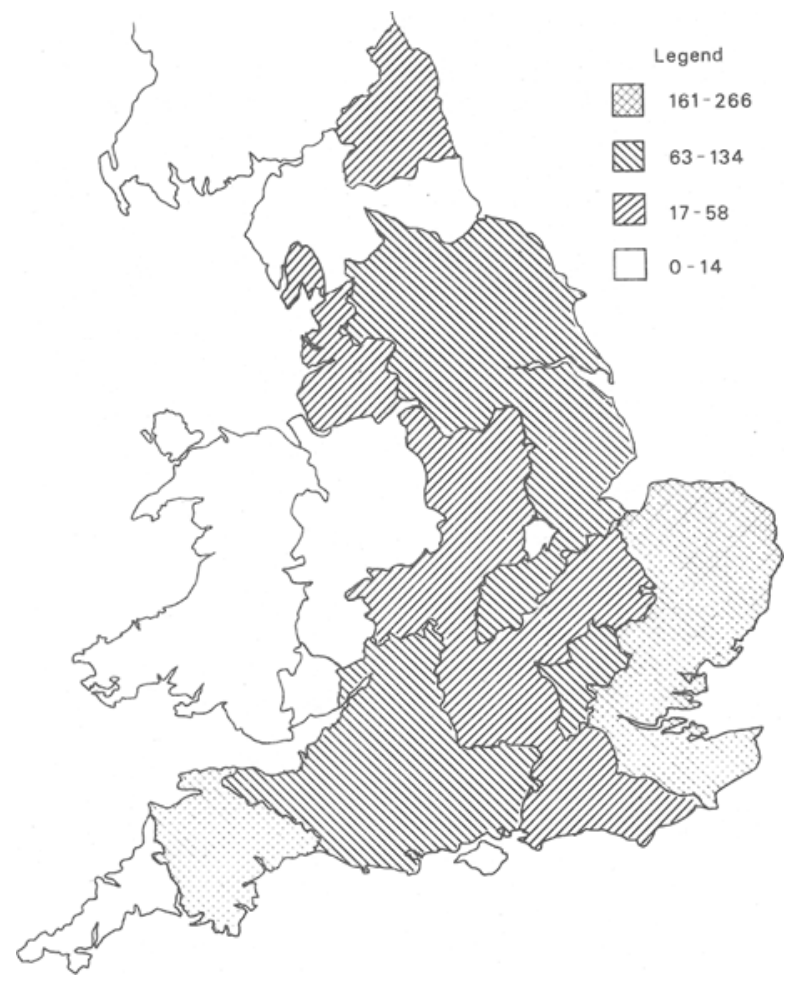

Figure 2. Density map of the geographical origins of more than 2,600 heads of families who came to New England between 1620 and 1640, based on Banks' research. those families most likely to produce eminent scientists from the very areas that Galton (1874) considered deficient, and 2 centuries later these English areas were still deficient.

Journalistic imagination aside, the early New England colonists were not rag-tag and bobtail working-class folk out of jobs and out of land. On the contrary, the early settlers in English North America tended to come from the higher class families that leave records of themselves; otherwise, Banks (1930) would not have been able to identify the geographical origins of so many. Recent investigations of colonial towns such as Salem (Gildrie, 1975) and Sudbury (Powell, 1963) are revealing a more stratified social structure than equalitarians might have supposed. In a detailed study of another early Massachusetts town, a number of demographic variables were sought from colonial records, including occupations, property, parish origins, and literacy (Crandall \& Coffman, 1977). In 17th century Charlestown, a total of 273 heads of families were thus examined. For 139 of these, no information could be found regarding literacy. Of the remainder, 110 left evidence, on wills, petitions, and so forth, that they were literate, and 24 left evidence that they were not. All things considered, this seems a high literacy rate for the period and would suggest upper class ancestry or high intelligence, or both, for the Charlestown immigrants. It is unfortunate that a recent report on the social ecology of IQ in the British Isles groups its data by standard regions, rather than counties, so it is impossible to make a direct comparison with the Banks map (Lynn, 1979). Visher's (1947) study of the ancestral origins of the American starred scientists found a preponderance of them to be of Puritan background. In another context, Visher also named 10 presidents of American universities who were outstanding in the science faculties they built up. Examining the ancestry of these effective university leaders, I find the following to be descendants of 17 th century English families settling in New England: D. C. Gilman, G. S. Hall, A. D. White, C. W. Eliot, J. B. Angell, D. S. Jordan, S. Low, and possibly T. C. Chamberlain and R. A. Millikan.

While the first Maine and New Hampshire settlers tended to be merchants and planters looking for profits on their investments, the Bay Colony settlers were religious purists who considered the established church to be corrupt and the English government too liberal (Bolton, 1929/1974; Spencer, 1930). Except for the servants and the fishermen, they were people of substance and property, or they would not have been able to afford the expensive trip "beyond seas." The failure of the Plymouth colonists to return a recompense to the merchants who financed their removal virtually ended opportunities for the poor to come on credit (Willison, 1945). The Reverend John White had hoped that America would provide a place to support some of the teeming impoverished of England, but at the hands of the Puritans 
who succeeded to the patent, America became instead a place for the minor gentry and rising yeoman and artisan families to escape high taxation and enjoy more fully the fruits of their efforts (Rose-Troup, 1930a, 1930b). These people were often well educated; they read books; some wrote books. Not only were some of them college graduates, but they immediately set about creating a public school system that is still enviable. Their policy of keeping exhaustive records made America the only major country in the world to have recorded its own beginnings.

It is understood that the genetic and social characteristics of American scientists have undergone profound changes in the last several generations (Elliott, 1982). But this in no way weakens the surmise that there was once a most consequential brain drain of families that did not subsequently create scientists in England but created them instead in America.

\section{REFERENCES}

BANKs, C. E. The planters of the commonwealth. Boston: Banks, 1930.

BANKs, C. E. Topographical dictionary of 2885 English emigrants to New England 1620-1650. Philadelphia: Brownell, 1937.

Bolton, C. K. The real founders of New England. Baltimore, Md: Genealogical Publishing Company, 1974. (Originally published, 1929.)

BreEn, T. H. Transfer of culture: Chance and design in shaping Massachusetts Bay. New England Historical and Genealogical Register, 1978, 132, 3-17.

CoLE, T. R. Family, settlement, and migration in southeastern Massachusetts, 1650-1805: The case for regional analysis. New England Historical and Genealogical Register, 1978, 132, 3-17.

Crandall, R. J., \& Cofrman, R. J. From emigrants to rulers: The Charlestown oligarchy in the great migration. New England
Historical and Genealogical Register, 1977, 131, 3-27; 121-132; 207-213.

DAvis, B. D. Social determinism and behavioral genetics. Science, 1975, 189, 1049.

Elliotr, C. E. Models of the American scientist: A look at collective biography. Isis, 1982, 73, 77-93.

Fancher, R. E. Galton in Africa. American Psychologist, 1982, 37, 713-714.

Galton, F. Hereditary genius: An inquiry into its laws and consequences. London: Macmillan, 1869.

Galton, F. English men of science: Their nature and nurture. London: Macmillan, 1874.

GILDRIE, R. P. Salem, Massachusetts (1626-1683): A convenant community. Charlottesville: University Press of Virginia, 1975.

GLenn, T. A. Welsh founders of Pennsylvania (2 vols). Baltimore, Md: Genealogical Publishing Company, 1970. (Originally published, 1911, 1913.)

Hanna, C. A. The Scotch-Irish; or, The Scot in North Britain, North Ireland, and North America. Baltimore, Md: Genealogical Publishing Company, 1968. (Originally published, 1902.)

LYNN, R. The social ecology of intelligence in the British Isles. British Journal of Social and Clinical Psychology, 1979, 18, 1-12.

Pope, C. H. The pioneers of Massachusetts. Boston: Pope, 1900.

Powels, S. C. Puritan village: The formation of a New England town. Middleton, Conn: Wesleyan University Press, 1963.

Rose-Troup, F. John White the patriarch of Dorchester (Dorset) and the founder of Massachusetts (1575-1648). New York: Putnam, 1930. (a)

Rose-Troup, F. The Massachusetts Bay Colony and its predecessors. New York: Putnam, 1930. (b)

Spencer, W. D. Pioneers on Maine rivers. Portland, Maine: Spencer, 1930.

VIsHer, S. S. Scientists starred 1903-43 in "American Men of Science": A study of collegiate and doctoral training, birthplace, distribution, backgrounds, and developmental influences. Baltimore, Md: Johns Hopkins Press, 1947.

Willison, G. F. Saints and strangers. New York: Reynal \& Hitchcock, 1945.

(Received for publication January 17, 1983.) 